\title{
Growth and Chemical Composition of Vicia faba L. Intercropped with Insectary Plants
}

\author{
Janina Gospodarek ${ }^{1 *}$, Barbara Biniaś ${ }^{1}$, Aleksandra Nadgórska-Socha ${ }^{2}$ \\ ${ }^{1}$ Department of Agricultural Environment Protection, University of Agriculture, \\ al. A. Mickiewicza 21, 31-120 Kraków, Poland \\ ${ }^{2}$ Department of Ecology, University of Silesia, Bankowa 9, 40-007 Katowice, Poland
}

Received: 9 October 2018

Accepted: 27 December 2018

\begin{abstract}
The objective of the study was to find the impact of accompanying plants (sweet alyssum Lobularia maritima L. and white mustard Sinapis alba L.) upon the growth and chemical composition of broad bean (Vicia faba L.). The assessments were performed by applying the diversified row spacing of broad bean plants and with the use of thinning of the accompanying plant (white mustard) in order to avoid competition. Both accompanying plants beneficially affected broad bean growth. The nitrogen content in the leaves of broad beans accompanied by L. maritima with the retained standard row spacing of $50 \mathrm{~cm}$ and $S$. alba with a $65 \mathrm{~cm}$ row spacing significantly decreased (by approx. $6 \%$ ), which can signify the competition for this element from both plants. The content of macroelements was diverse: in the case of $\mathrm{Mg}$ and $\mathrm{P}$, the decreased content was noted, while the contents of $\mathrm{Ca}$ and $\mathrm{K}$ in some cases increased under the effect of the applied method of protection. The content of microelements and heavy metals usually either did not fluctuate widely, or increased ( $\mathrm{Fe}, \mathrm{Ni}$, and $\mathrm{Al}$ ). Only in the case of $\mathrm{Zn}$ was there evident decrease in its content in broad beans growing close to L. maritima plants.
\end{abstract}

Keywords: competition, nutrients, heavy metals, mixed crops, white mustard, sweet alyssum

\section{Introduction}

Adding plants to accompany the main crop has a number of applications essential from the viewpoint of both agricultural and environmental practices. Among these, the fundamental reasons are as follows: providing the main crop plants with protection against pests, diseases, and weeds, without the necessity to reach out to chemical plant protection (which has a direct positive

*e-mail: rrjgospo@cyf-kr.edu.pl effect on the environment); better utilization of nutrients and water; and ensuring greater yield. Intercropping is also considered to be a crucial factor for enhancing the success of gentle soil remediation options (GRO) application [1].

The use in intercropping of so-called "insectary plants," i.e., plants of a proven positive effect on the beneficial entomofauna, could provide an alternative to the protection of plants involving the use of insecticides [2]. This is crucial in ecological farming systems where we cannot use chemicals. A particular importance is contributed here to pollen- and nectar-giving plants, constituting a source of food for the imago form of 
many predatory and parasitic insects. In this way, these plants can enhance the natural mechanisms limiting pests [3-5].

White mustard (Sinapis alba L.) is an example of a pollen- and nectar-giving plant. It has found wide application as a component of mixed cultivations due to its limiting such pests as the pea weevil Sitona spp. [6], pea thrips Kakothrips robustus Uzel [7], black bean aphid Aphis fabae Scop. [8], and the root-knot nematode Meloidogyne spp. [9]. The deep root system of $S$. alba enhances aeration/redox potential and, as a consequence, can affect the uptake of nutrients and the chemical composition of nearby growing plants [10]. Its presence in cultivation can also modify the root system of the main crop plant, and thus affect the better use of nutrients and water [11]. However, it is a fastgrowing plant, with a considerable aboveground mass; therefore, it can constitute a remarkable competition for the main crop. As a result, the choice of correct plant spacing of both components in mixed sowing is a very important factor. The solution may also be the thinning of the accompanying plant at a certain moment of its growth in order to limit competition toward the main crop.

Sweet alyssum (Lobularia maritima L.) is also a plant included in "insectary plants" $[12,13]$. In the literature, there is an extensive emphasis attached to the luring capacity of this plant toward the natural enemies of the pests, particularly the dipterans of the Syrphidae family [14-16], and the parasitic hymenopterans $[17,18]$. To be able to fulfil this function, the plant must be properly exposed (it has to be visible and easily accessible to the insects using its pollen or nectar), and that can be achieved by the correct selection of row spacing [19].

The neighbourhood of two plants affects their growth, and can essentially modify their chemical composition. The competition for nutrients, microelements, and water, or the effect of substances released by roots upon the solubility and bioavailability of certain elements, can be of importance [1]. The available studies on the use of "insectary plants" in intercropping concentrate principally on the effectiveness of this kind of action upon the limitation of pests, and there is the lack of information on their impact upon the macro- and microelements in the main crop plant. Changes in the composition of the main plant may also be related to the distance between both components.

The objective of the presented studies was to find the impact of accompanying plants (sweet alyssum and white mustard) along with the aim of protection against pests upon the growth and chemical composition of the protected main crop plant - the broad bean (Vicia faba L.). The assessments were performed applying the diversified row spacing of broad bean plants and with the use of thinning of the accompanying plant (white mustard) in a predefined time in order to eliminate the excessive competition toward the main crop plant.

\section{Material and Methods}

\section{Experimental Design}

The field experiment was set up in the Experimental Station of the University of Agriculture in Krakow, located in Prusy near Krakow, Poland $\left(50^{\circ} 07^{\prime} 02.5^{\prime \prime} \mathrm{N}\right.$ $20^{\circ} 05^{\prime} 18.3^{\prime \prime} \mathrm{E}$ ), in an area that has been used for six years for conducting cultivation by ecological methods. The soil in the experimental site is degraded Chernozem originating from loess with the granulometric composition of silt loam. The soil analysis conducted prior to setting up the experiment showed that the soil reaction approximated the neutral reaction $(\mathrm{pH}$ in $\mathrm{H}_{2} \mathrm{O}=6.56 ; \mathrm{pH}$ in $\mathrm{KCl}=5.70$ ) and $2.28 \%$ of humus content. The content of available nutrients was as follows: $\mathrm{N}-\mathrm{NO}_{3}=5.85 \mathrm{mg} \mathrm{kg}^{-1}$ soil fresh mass, $\mathrm{N}-$ total $=0.14 \%$, $\mathrm{P}_{2} \mathrm{O}_{2}=22.0 \mathrm{mg} 100 \mathrm{~g}^{-1}, \mathrm{~K}_{2} \mathrm{O}=27.0 \mathrm{mg} 100 \mathrm{~g} \mathrm{~g}^{-1}$, $\mathrm{Mg}=8.5 \mathrm{mg} 100 \mathrm{~g}^{-1}, \mathrm{~B}=1.65 \mathrm{mg} \mathrm{kg}^{-1}, \mathrm{Mn}=176.4 \mathrm{mg} \mathrm{kg}^{-1}$, $\mathrm{Cu}=4.40 \mathrm{mg} \mathrm{kg}{ }^{-1}, \mathrm{Zn}=27.73 \mathrm{mg} \mathrm{kg}$, and $\mathrm{Fe}=1081 \mathrm{mg} \mathrm{kg}^{-1}$ of soil. The soil analysis was performed in the Regional Chemical-Agricultural Station in Krakow. The broad bean (Vicia faba L.) variety Bartek was cultivated in companion planting with the sweet alyssum (Lobularia maritima L.) variety Capri and the white mustard (Sinapis alba L.) variety Bardena in differentiated row spacings. Because of the earlier-documented competition of white mustard toward Fabaceae plants, in the case of this plant, after the broad bean plants reached the beginning of the flower bud formation phase, one half of the objects with white mustard as a companion plant was subject to thinning (every second white mustard plant was uprooted). In the initial period of broad bean growth, white mustard does not constitute competition toward the main crop plant, and for the latter to show the limiting effect against the pests attacking emerging broad bean plants (pea weevils), a great density of white mustard plants is desirable, and in line with the growth of both broad bean and white mustard (both plants grow fairly fast and in the similar rate), the competition starts to show. Thus, the white mustard exerts a limiting effect on the flowering of broad beans and slows down pod setting; therefore, the thinning of white mustard plants was introduced at that time in order to limit the competitiveness while simultaneously retaining the role of flowers as attractants. A homogenous cultivation of the broad bean with a row spacing of $50 \mathrm{~cm}$ constituted the control, and the identical cultivation subjected to standard pest protection employing chemical insecticides (Decis 2.5 EC and Fastac 100 EC) provided reference to the conventional protection measures. In the object with chemical protection measures, each chemical preparation was applied twice. In order to combat the pea weevil (Sitona sp.), Fastac 100 EC pesticide was used at a dose of $0.09 \mathrm{l} /$ hectare, applied at the time of the first observed damage by agrophages, and repeated after 7 days. The control of the broad bean weevil (Bruchus rufimanus Boh.) and black bean aphid (Aphis 
fabae Scop.) was performed by the application of Decis 2,5 EC pesticide at a dose of $0.251 /$ hectare. The first application was done at the time of the appearance of aphids on the broad beans. The subsequent procedure was applied during the stage of blossom fall of the first vertical level of inflorescences as a protective measure against the broad bean weevil. The $15 \mathrm{~cm}$ row spacing between the broad bean plants was established on the basis of cultivation recommendations for this species. The seeds were placed in the soil at a depth of $6 \mathrm{~cm}$. The white mustard was sown between the rows of beans at the same time as the beans were sown, in a quantity per hectare lower by one-third compared with the norm predicted for the cultivation of seeds. The sweet alyssum was sown into multipots (15 seed to one cell of a multipot, measuring $2.5 \mathrm{~cm} \times 2.5 \mathrm{~cm}$ ), and it was later grown in a greenhouse. The small clusters of plants were planted immediately after the emergence of broad bean plants in rows between the rows of the main crop and spaced at $25 \mathrm{~cm}$ in the row. Throughout the experiment, the weed control was carried out mechanically. The area of the single plot was $25 \mathrm{~m}^{2}$. The experiment was made in four repetitions. In order to avoid the effect of neighbourhood influences, the control objects and those objects where chemical pest protection procedures were applied had been situated $50 \mathrm{~m}$ from the plots with the companion planting, and this buffer area was sown with oats. Particular plots with companion planting and the control plots as well as those with chemical pest control were separated from one another with 3-metre wide strips of oats. Because of their neutrality toward the pests of Fabaceae plants, similar buffer zones using cereals (1.25 metre-wide strips) were used by other authors in their earlier studies on the effects of companion planting upon the natural enemies of pests [4].

The following experimental objects were established:

- Broad bean with sweet alyssum with $50 \mathrm{~cm}$ row spacing (L50).

- Broad bean with sweet alyssum with $65 \mathrm{~cm}$ row spacing (L65).

- Broad bean with sweet alyssum with $80 \mathrm{~cm}$ row spacing (L80).

- Broad bean with white mustard with $65 \mathrm{~cm}$ row spacing, not thinned (S65).

- Broad bean with white mustard with $80 \mathrm{~cm}$ row spacing, not thinned (S80).

- Broad bean with white mustard with $65 \mathrm{~cm}$ row spacing, thinned (St65).

- Broad bean with white mustard with $80 \mathrm{~cm}$ row spacing, thinned (St80).

- Broad bean in homogenous cultivation with $50 \mathrm{~cm}$ row spacing - the control (Control).

- Broad bean in homogenous cultivation, with $50 \mathrm{~cm}$ row spacing, subjected to standard chemical pest control measures $(\mathrm{Ch})$.

\section{Broad Bean Growth}

The assessment of plant morphology was conducted in the phase of technological (milk) maturity of the broad bean seeds. Ten plants were collected at random from each plot, and the following elements were then determined: the aboveground part mass and mass of roots, the number of leaves and seeds, and the mass of seeds. The yield of seeds was also determined. Simultaneously, the samples for the analysis of the chemical composition of plants were collected.

\section{Elements Content in Broad Bean Plants}

In order to determine the concentrations of macro and microelements in the leaves of plants, plant material was cleaned of any patches of deposited aphid honeydew and other surface contaminants, washed in tap and then distilled water. It was then dried at $105^{\circ} \mathrm{C}$. A portion of $0.25 \mathrm{~g}$ dried plant material was digested with $5 \mathrm{ml}$ of $\mathrm{HNO}_{3}$ at $120^{\circ} \mathrm{C}$ and then diluted to $25 \mathrm{ml}$ with deionized water. Next, the metal content was measured using flame absorption spectrometry (Thermo Scientific iCE 3500) [20]. The carbon, nitrogen, and sulphur contents were determined in a Variomax CNS analyzer.

\section{Statistical Analysis}

The obtained results were then subjected to analysis by STATISTICA 10.0 software. The significance of differences between the means were tested by one-factor variance analysis, and the means were differentiated by Tukey's test at $\alpha=0.05$.

\section{Results and Discussion}

\section{Broad Bean Growth}

Among the pests of broad bean, the most important is the black bean aphid [21, 22]. Its occurrence leads to a major limitation of vegetative growth, dying out of flowers, and the lack of pod and seed formation. The principal objective for insectary plants employed in the presented study was to limit the occurrence of this pest, which was, nevertheless, successful to a great extent [8]. On the one hand, it translated into the growth of broad beans, and the lowest values of morphological parameters were found in the object not protected in any way (Table 1). On the other hand, the majority of these parameters achieved the highest values in the object where the standard chemical, insecticide-based protection was applied. It was yet another expected effect, because biological protection is usually less effective than chemical protection. Among the objects with sweet alyssum as the accompanying plant, the highest values of all parameters pertaining to single plants were determined in the objects with $80 \mathrm{~cm}$ row spacings of broad bean plants. This can be explained by 
Table 1. Morphological parameters of broad bean plants and yields.

\begin{tabular}{|c|c|c|c|c|c|c|}
\hline Treatments & $\begin{array}{c}\text { Mass of aboveground part } \\
{\left[\mathrm{g} \text { plant }{ }^{-1}\right]}\end{array}$ & $\begin{array}{c}\text { Mass of root } \\
{\left[\mathrm{g} \text { plant }{ }^{-1}\right]}\end{array}$ & $\begin{array}{c}\text { Number of leaves } \\
\text { per plant [pcs] }\end{array}$ & $\begin{array}{c}\text { Number of seeds } \\
\text { per plant [pcs] }\end{array}$ & $\begin{array}{c}\text { Mass of seeds } \\
\text { per plant [g] }\end{array}$ & $\begin{array}{c}\text { Yield of seeds } \\
{\left[\mathrm{g} \mathrm{m^{-2 }}\right]}\end{array}$ \\
\hline L50 & $253.87^{\mathrm{abc}}$ & $30.92^{\mathrm{a}}$ & $38.60^{\mathrm{ab}}$ & $17.77^{\mathrm{ab}}$ & $42.07^{\mathrm{b}}$ & $560.75^{\mathrm{c}}$ \\
\hline L65 & $233.43^{\mathrm{ab}}$ & $25.77^{\mathrm{a}}$ & $36.07^{\mathrm{ab}}$ & $16.60^{\mathrm{a}}$ & $36.33^{\mathrm{ab}}$ & $372.42^{\mathrm{ab}}$ \\
\hline L80 & $271.00^{\mathrm{abc}}$ & $42.73^{\mathrm{b}}$ & $41.27^{\mathrm{b}}$ & $24.30^{\mathrm{abc}}$ & $47.48^{\mathrm{bc}}$ & $395.54^{\mathrm{b}}$ \\
\hline S65 & $288.97^{\mathrm{bc}}$ & $23.75^{\mathrm{a}}$ & $35.47^{\mathrm{ab}}$ & $28.10^{\mathrm{c}}$ & $53.83^{\mathrm{bc}}$ & $551.79^{\mathrm{c}}$ \\
\hline S80 & $288.93^{\mathrm{bc}}$ & $23.02^{\mathrm{a}}$ & $38.33^{\mathrm{ab}}$ & $26.17^{\mathrm{abc}}$ & $44.97^{\mathrm{bc}}$ & $374.57^{\mathrm{ab}}$ \\
\hline St65 & $292.80^{\mathrm{bc}}$ & $24.80^{\mathrm{a}}$ & $36.00^{\mathrm{ab}}$ & $26.93^{\mathrm{bc}}$ & $53.67^{\mathrm{bc}}$ & $550.08^{\mathrm{c}}$ \\
\hline St80 & $309.97^{\mathrm{c}}$ & $20.52^{\mathrm{a}}$ & $40.17^{\mathrm{ab}}$ & $27.00^{\mathrm{bc}}$ & $46.37^{\mathrm{bc}}$ & $386.23^{\mathrm{b}}$ \\
\hline Ch & $393.10^{\mathrm{d}}$ & $24.92^{\mathrm{a}}$ & $40.07^{\mathrm{ab}}$ & $39.50^{\mathrm{d}}$ & $61.97^{\mathrm{c}}$ & $826.02^{\mathrm{d}}$ \\
\hline Control & $206.90^{\mathrm{a}}$ & $23.99^{\mathrm{a}}$ & $32.97^{\mathrm{a}}$ & $16.67^{\mathrm{a}}$ & $18.98^{\mathrm{a}}$ & $253.05^{\mathrm{a}}$ \\
\hline
\end{tabular}

L50 - broad bean with sweet alyssum with $50 \mathrm{~cm}$ row spacing, L65 - broad bean with sweet alyssum with $65 \mathrm{~cm}$ row spacing, L80 - broad bean with sweet alyssum with $80 \mathrm{~cm}$ row spacing, S65 - broad bean with white mustard with $65 \mathrm{~cm}$ row spacing, not thinned, S80 - broad bean with white mustard with $80 \mathrm{~cm}$ row spacing, not thinned, St65 - broad bean with white mustard with $65 \mathrm{~cm}$ row spacing, thinned, St 80 - broad bean with white mustard with $80 \mathrm{~cm}$ row spacing, thinned, $\mathrm{Ch}$ - broad bean in homogenous cultivation, with $50 \mathrm{~cm}$ row spacing, subjected to standard chemical pest control measures, Control - broad bean in homogenous cultivation with $50 \mathrm{~cm}$ row spacing, not protected. *Values marked by different letters are statistically different $(\alpha=0.05)$.

the increased row spacing. However, with the standard $50 \mathrm{~cm}$ row spacing (the same as in the control object), the seed mass per plant was significantly (more than twofold) higher than in the unprotected object. The seed yield was also the highest whenever the standard row spacing, i.e. $50 \mathrm{~cm}$, was retained. Next, both row spacings, i.e. $65 \mathrm{~cm}$ and $80 \mathrm{~cm}$, applied in the cultivation of broad beans with white mustard did not differ significantly between them in terms of the effect upon the growth of broad bean plants. However, the higher density of plants in the row spacing of $65 \mathrm{~cm}$ resulted in a significantly higher yield. The thinning procedure applied to the accompanying plant did not significantly affect the morphological features of the $V$. faba plants. The mass of aboveground parts, including the mass of seeds per plant, was higher than in the unprotected homogeneous cultivation of broad beans in each of the objects where the $V$. faba plants were accompanied by $S$. alba plants. In the presented experiment, the presence of sweet alyssum resulted in the increase in yield by approx. 47-121\%. In comparison, introducing $L$. maritima as an accompanying plant in the cultivation of broccoli attracts hoverflies (Diptera: Syrphidae), which are important predators of aphids $[23,24]$ and permits an increase in broccoli shoots by $31-67 \%$ in comparison to broccoli monoculture [25]. Owing to the wider row spacing, the presence of white mustard did not adversely affected the seed yield; although, as indicated by literature, this plant cultivated in companion planting with the faba bean contributed to a marked decrease in the faba bean seed yield (approx. twofold) [11].

\section{Macroelements Content in Broad Bean Plants}

The presence of two plant species growing alongside each other can lead to their competition for nutrients, and it can result in decreases in the content of macro- and microelements in plant tissues [26, 27]. In the presented experiment, the nitrogen content in the leaves of broad bean plants under the effect of $L$. maritima plants growing nearby, retaining the standard row spacing of $50 \mathrm{~cm}$, decreased by approx. $2 \mathrm{~g} \mathrm{~kg}^{-1}$ (Table 2). A similar situation was found in broad beans cultivated with white mustard with the smaller row spacing, i.e., $65 \mathrm{~cm}$. In the latter case, the thinning procedure applied to $S$. alba resulted in the increase in $\mathrm{N}$ content. The highest nitrogen content was found in the leaves of broad beans cultivated alone, protected chemically, which confirms the above-presented hypothesis of competitiveness. A similar tendency was noted in the case of faba bean intercropped with white mustard [11]. The total shoot nitrogen accumulation was about $6 \mathrm{~g} \mathrm{~m}^{-2}$ lower when faba bean was grown with mustard than when it grown alone. The type of soil is also of importance. At site with loess soil of high soil fertility, which was similar to soil in our experiment, the authors found that the differences in this parameter ( $\mathrm{N}$ accumulation) were more pronounced than on a clayey-silty to sandy-silty floodplain sediment. The loess soil was rich in available soil-born nitrogen, what strengthened competiveness from mustard. In the same research, plant-available soil nitrogen concentration was higher in the objects where faba bean grown as a sole crop. According to the authors it was caused by heterogenous root distribution of a relatively low rootlength density in a sole crop. In intercroped crops root density was enhanced and its distribution was more 
Table 2. Contents of nitrogen, carbon and sulphur in broad bean leaves $\left[\mathrm{g} \mathrm{kg}^{-1}\right]$.

\begin{tabular}{|c|c|c|c|c|}
\hline Treatments & $\mathrm{N}$ & $\mathrm{C}$ & $\mathrm{S}$ & C:N ratio \\
\hline L50 & $36.78^{\mathrm{a}^{*}}$ & $398.32^{\mathrm{ab}}$ & $1.34^{\mathrm{a}}$ & $10.83^{\mathrm{b}}$ \\
\hline L65 & $39.59^{\mathrm{bc}}$ & $396.59^{\mathrm{ab}}$ & $1.55^{\mathrm{ab}}$ & $10.02^{\mathrm{a}}$ \\
\hline L80 & $40.01^{\mathrm{bc}}$ & $402.09^{\mathrm{c}}$ & $1.45^{\mathrm{ab}}$ & $10.05^{\mathrm{a}}$ \\
\hline S65 & $36.86^{\mathrm{a}}$ & $398.78^{\mathrm{bc}}$ & $1.29^{\mathrm{a}}$ & $10.82^{\mathrm{b}}$ \\
\hline S80 & $39.09^{\mathrm{bc}}$ & $397.45^{\mathrm{ab}}$ & $1.47^{\mathrm{ab}}$ & $10.17^{\mathrm{a}}$ \\
\hline St65 & $38.71^{\mathrm{b}}$ & $395.95^{\mathrm{ab}}$ & $1.36^{\mathrm{a}}$ & $10.23^{\mathrm{a}}$ \\
\hline St80 & $36.70^{\mathrm{a}}$ & $395.03^{\mathrm{a}}$ & $1.37^{\mathrm{a}}$ & $10.77^{\mathrm{b}}$ \\
\hline Ch & $40.37^{\mathrm{c}}$ & $397.79^{\mathrm{ab}}$ & $1.47^{\mathrm{ab}}$ & $9.85^{\mathrm{a}}$ \\
\hline Control & $39.08^{\mathrm{bc}}$ & $399.67^{\mathrm{bc}}$ & $1.76^{\mathrm{b}}$ & $10.23^{\mathrm{a}}$ \\
\hline
\end{tabular}

Symbols as in Table $1 .{ }^{*}$ Values marked by different letters are statistically different $(\alpha=0.05)$.

regular, which allows for enhanced nitrogen acquisition. Also, other studies support the fact that soil mineral nitrogen can be reduced by intercropping legume with non-legume [28].

The carbon contents in the leaves of broad bean plants collected in particular objects were very similar. The differences stayed within the approximate limits from 2 to $7 \mathrm{~g} \mathrm{~kg}^{-1}$. The highest content of this element was found in the leaves of broad bean plants cultivated with sweet alyssum with a $80 \mathrm{~cm}$ row spacing. The sulphur content was also similar in particular objects (the maximum difference amounted to $0.47 \mathrm{~g} \mathrm{~kg}^{-1}$ ). The highest sulphur content was found in the leaves of unprotected broad bean plants. The C:N ratio attained the values from 9.85 to 10.83 , with the lowest value determined in the leaves of insecticide-protected broad bean plants. Next, the highest values were noted in the objects with accompanying plants in smallest row spacing and in the object with white mustard with 80 $\mathrm{cm}$ row spacing and subjected to thinning.

Under the effect of the applied methods of protection (both chemical and via the companion planting), the magnesium and phosphorus content in the leaves of broad beans decreased while the calcium and potassium content increased after some actions (Table 3). The $\mathrm{Mg}$ content decreased by approx. $11.5 \%$ (St 65 ) to $26 \%$ (L80) compared with the unprotected object. Only in L50 and L65 objects did these values not differ significantly compared with the control. A similar decrease in the $\mathrm{Mg}$ uptake by chickpea, with a simultaneous increase in $\mathrm{Mg}$ uptake by wheat was noted by Li et al. [29] in their experiment pertaining to the effect of the close presence of these plants and the various forms of phosphorus upon the composition of both species. The concentration of $\mathrm{Mg}$ also decreased in cucumber plants cultivated together with green garlic, compared to monoculture [30]. The authors explained it with antagonistic effects between $\mathrm{K}, \mathrm{Ca}$ and $\mathrm{Mg}$. In their study, concentrations of $\mathrm{K}$ and $\mathrm{Ca}$ increased in intercropped treatment and $\mathrm{Mg}$ decreased. The same effect was observed in our study.
On the other hand, in the case of $\mathrm{P}$ in all protected objects in the presented experiment, the values obtained were significantly lower (by a maximum of approx. $31.5 \%$ for L80 object and a minimum of approx. $9 \%$ for Ch object) than in the control object. Therefore, it can be supposed that, similarly as in the cases of $\mathrm{N}$ and $\mathrm{Mg}$, the accompanying plants compete for this element with the main crop plant, particularly because this decrease was relatively small in the chemically protected objects. It is also confirmed by the data obtained by $\mathrm{Li}$ et al. [29], who found that the intermingling of chickpea and wheat roots in mixed cultivation had a positive effect on $\mathrm{P}$ uptake by wheat and a negative effect on $\mathrm{P}$ uptake by chickpea, when phytate-P was used as a source of phosphorus. Similarly, in the leaves of wheat cultivated in companion planting with clover, the phosphorus content was higher compared with mono-cultivated plants [31]. The content of available phosphorous in our experimental soil was very high. It also may, similarly as in the case of nitrogen, improve competiveness from accompanying plants.

The increases in $\mathrm{Ca}$ content were the greatest in the objects where broad bean cultivation was accompanied by sweet alyssum in the medium and smallest row spacing (by approx. 33\%). Somewhat lower, but also significant, increases were observed in the objects with the greatest row spacing and also in some objects with white mustard (S80 and St65). In its turn, the increase in $\mathrm{K}$ content was noted solely in the chemically protected object (by approx. 38\%) and in the broad bean cultivation with $S$. alba in the greatest row spacing (by approx. $19.6 \%$ ). In the remaining objects, the $\mathrm{K}$ content in the leaves of broad bean was similar to that in the control object. Similar increases in $\mathrm{Ca}$ and $\mathrm{K}$ content were noted in leaves of wheat cultivated with clover [31], cucumber plants cultivated with green garlic [30], and in the case of $\mathrm{Ca}$ also in chickpea plants growing together with wheat with inorganic P [28]. In the study of Xiao et al. [30], the content of available $\mathrm{K}$ increased in the soil with increasing amounts of green garlic 


\begin{tabular}{|c|c|c|c|c|c|c|c|c|c|c|}
\hline & & ? & $\stackrel{\text { ̆ }}{\stackrel{\circ}{r}}$ & فํ. & 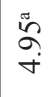 & $\begin{array}{l}\stackrel{\Xi}{0} \\
\stackrel{+}{+}\end{array}$ & 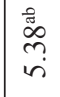 & $\stackrel{\stackrel{s}{f}}{\stackrel{P}{+}}$ & $\begin{array}{l}\stackrel{\sim}{\sigma} \\
\dot{+}\end{array}$ & 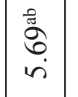 \\
\hline & & 5 & 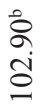 & 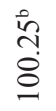 & $\begin{array}{l}\stackrel{0}{0} \\
\stackrel{0}{0} \\
=\end{array}$ & $\frac{\tilde{a}}{\hat{\sigma}}$ & $\begin{array}{l}\hat{i} \\
\stackrel{n}{j} \\
\stackrel{y}{J}\end{array}$ & 㞼 & 蒙 & $\begin{array}{l}\text { R. } \\
\text { م. } \\
\text { in }\end{array}$ \\
\hline & & $?$ & तें & స్ & के & 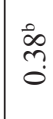 & \begin{tabular}{|l}
$\infty$ \\
$\infty$ \\
0 \\
0 \\
0
\end{tabular} & 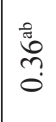 & $\begin{array}{c}\infty \\
\infty \\
0 \\
0\end{array}$ & $\begin{array}{l}\stackrel{0}{\tilde{n}} \\
\tilde{o} \\
0\end{array}$ \\
\hline & & 8 & $\frac{\stackrel{g}{g}}{\stackrel{d}{0}}$ & ثิ & & 胥 & $\frac{\stackrel{\nexists}{\overparen{Z}}}{\stackrel{0}{0}}$ & $\frac{\stackrel{g}{g}}{0}$ & $\stackrel{\stackrel{0}{\overparen{Z}}}{0}$ & 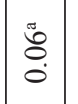 \\
\hline & & 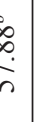 & $\begin{array}{l}\frac{\bullet}{0} \\
\text { in }\end{array}$ & $\begin{array}{l}\stackrel{2}{2} \\
\dot{f} \\
\dot{n}\end{array}$ & $\begin{array}{l}\stackrel{8}{0} \\
\stackrel{8}{\vec{n}} \\
\text { n. }\end{array}$ & $\begin{array}{l}\overrightarrow{8} \\
\dot{0} \\
\dot{n}\end{array}$ & $\begin{array}{l}\stackrel{a}{g} \\
\dot{g} \\
\text { in }\end{array}$ & $\begin{array}{l}\tilde{z} \\
\tilde{n} \\
i n \\
n\end{array}$ & 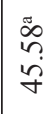 & $\frac{\frac{\sigma}{\sigma}}{\sigma}$ \\
\hline & & b. & 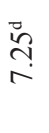 & 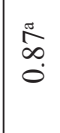 & 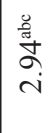 & 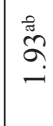 & 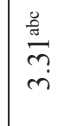 & 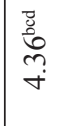 & 葛 & 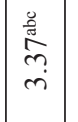 \\
\hline & & & 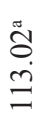 & 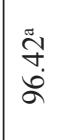 & مُ & 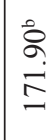 & $\begin{array}{l}\text { बे. } \\
\text { రై }\end{array}$ & 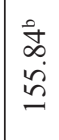 & 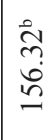 & $\begin{array}{l}\stackrel{0}{0} \\
0 \\
\stackrel{0}{0} \\
=\end{array}$ \\
\hline & & & 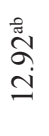 & 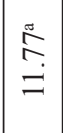 & 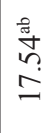 & 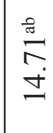 & 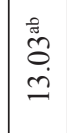 & 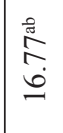 & $\begin{array}{l}\overrightarrow{\vec{\alpha}} \\
\dot{\infty} \\
\dot{0}\end{array}$ & 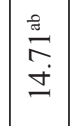 \\
\hline & & & $\begin{array}{l}\stackrel{8}{\dddot{q}} \\
\stackrel{8}{8} \\
\stackrel{0}{0}\end{array}$ & $\frac{\pi}{m}$ & 官 & 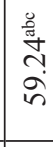 & 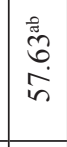 & 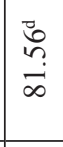 & $\begin{array}{l}\stackrel{8}{\circ} \\
\stackrel{2}{0} \\
\dot{f}\end{array}$ & 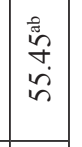 \\
\hline & & & 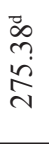 & 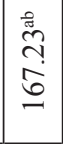 & 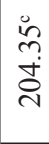 & 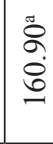 & 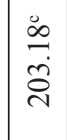 & $\begin{array}{l}0 \\
\dot{0} \\
0 \\
0 \\
\stackrel{\sim}{N}\end{array}$ & 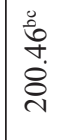 & 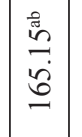 \\
\hline & & w & 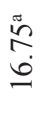 & 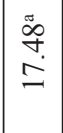 & 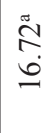 & 产 & 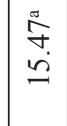 & 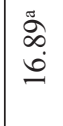 & 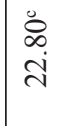 & 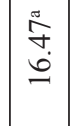 \\
\hline & & $\widehat{\sigma}$ & $\frac{8}{8}$ & $\begin{array}{l}\stackrel{\widetilde{J}}{\sigma} \\
\dot{\sim}\end{array}$ & 总 & $\begin{array}{l}\hat{n} \\
\text { nู }\end{array}$ & $\begin{array}{l}\stackrel{0}{\infty} \\
\stackrel{0}{0}\end{array}$ & $\begin{array}{l}\stackrel{B}{0} \\
\stackrel{1}{r}\end{array}$ & $\underset{\stackrel{\overbrace{}}{f}}{\stackrel{2}{\sim}}$ & $\underset{\infty}{\stackrel{\sim}{\infty}}$ \\
\hline & 8 & $m$ & $\begin{array}{l}\text { 苞 } \\
\text { ḋ }\end{array}$ & 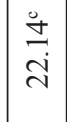 & 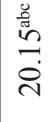 & 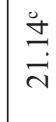 & $\begin{array}{l}0 \\
\infty \\
\infty \\
\infty \\
\stackrel{\sim}{0}\end{array}$ & 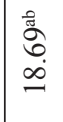 & $\begin{array}{l}\underset{\sim}{\sim} \\
\stackrel{g}{-}\end{array}$ & 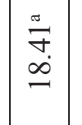 \\
\hline & $\sum^{20}$ & $\infty$ & 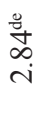 & 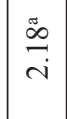 & $\begin{array}{l}\vec{z} \\
\tilde{o} \\
i \\
i\end{array}$ & $\mid$ & $\begin{array}{l}\vec{D} \\
\vec{i} \\
i\end{array}$ & 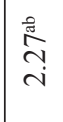 & 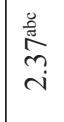 & $\begin{array}{l}\ddot{n} \\
\dot{\gamma}\end{array}$ \\
\hline & & & 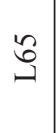 & 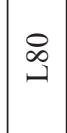 & $\begin{array}{l}n \\
b \\
w\end{array}$ & $\begin{array}{l}\stackrel{\otimes}{\infty} \\
\stackrel{2}{n}\end{array}$ & $\begin{array}{l}n \\
\stackrel{2}{\infty} \\
\infty\end{array}$ & $\begin{array}{l}\otimes \\
\ddot{\infty} \\
\ddot{\infty}\end{array}$ & $\tilde{U}$ & $\left|\begin{array}{l}\overline{0} \\
\stackrel{\Xi}{0} \\
0 \\
0\end{array}\right|$ \\
\hline
\end{tabular}

used as an accompanying plant in cucumber crop. A similar situation could occur in our experiment, which may partly explain observed increases in $\mathrm{K}$ content in broad bean plants. This thesis, however, requires further research.

\section{Microelements and Heavy Metals Content in Broad Bean Plants}

The content of $\mathrm{Fe}$ and $\mathrm{Mn}$ increased significantly in the leaves of broad bean plants growing in companion planting with $S$. alba in $65 \mathrm{~cm}$ row spacing and 80 $\mathrm{cm}$ row spacing, but after the thinning procedure (respectively by approx. $23 \%$ and $27 \%$, and $25 \%$ and $47 \%$ ). In the case of $\mathrm{Fe}$, the increase was also recorded in the cultivation of broad beans with sweet alyssum in medium row spacing (by approx. 67\%) and with white mustard in a $65 \mathrm{~cm}$ row spacing and with the application of the thinning procedure (by approx. 23\%). The intercropping of peanuts with maize resulted in the increase of $\mathrm{Fe}$ nutrition in the peanuts [32]. The authors gave the rhizosphere effect of maize and increase in the expression of genes responsible for $\mathrm{Fe}$ uptake in intercropped peanuts, compared to monocropped peanuts, as the reasons for the increase. The close presence of wheat did not significantly affect the concentration of iron in the shoots of chickpea but contributed to the increase in manganese content when accompanied by fertilising with inorganic phosphorus [29]. The neighbourhood of Lupinus albus L. resulted in the increase in $\mathrm{Fe}$ and $\mathrm{Mn}$ content in shoots of barley [33]. The Mn content also increased in cucumber plants under the effect of the intercropping with green garlic [30]. The authors explained that the effect increases in rhizosphere acidification, which enhances the availability of some nutrients in soil, particularly $\mathrm{Fe}$ and $\mathrm{Mn}$. In this research intercropping cucumber with garlic decreases $\mathrm{pH}$ in $\mathrm{H}_{2} \mathrm{O}$ from a value of 7.66 to a level of 7.27. This is also confirmed by the studies of Zuo et al. [34]. Compared to monocropping, the available iron concentration in peanut rhizosphere was increased in all intercropped cropping systems (i.e., peanuts with different gramineous species: maize, barley, oats, wheat). According to the findings by Maltais-Landry [35], mustard cultivation leads to a slight decrease in soil $\mathrm{pH}$. This may explain the observed increase in the Fe and $\mathrm{Mn}$ content in the broad bean leaves. Unfortunately, in the available literature there is lack of information about the influence of L. maritima cultivation on soil $\mathrm{pH}$ value.

The content of barium, strontium, and cadmium in the broad bean leaves did not alter much under the effect of protection applied, with the highest concentrations of barium noted in the leaves of chemically protected broad beans while, in the same object, strontium showed the lowest concentration. The leaves of broad bean plants cultivated together with L. maritima were characterised by the significantly lower content of zinc compared with the control object. The maximum decrease was found 
with the greatest row spacing, i.e. $80 \mathrm{~cm}$ (by approx. $46 \%$ ), and the minimum with medium row spacing of 65 cm (by approx. 36.5\%). Here again, the competition can play a certain role. A similar phenomenon was described by Gove et al. [36] in the case of Noccaea caerulescens, which decreased the $\mathrm{Zn}$ accumulation in co-cropped Hordeum vulgare. However, in scientific publications, it is emphasised that the effect of intercropping varied according to the various metals present. The Noccaea caerulescens mentioned above increased the $\mathrm{Cd}$ accumulation in co-cropped Hordeum vulgare. Here, the substances released from the roots of plants can be important, because they can affect the solubility of metal compounds and therefore change their availability. In the experiment conducted in the presented study, the cultivation of broad beans with sweet alyssum in medium row spacing resulted in the increased content of $\mathrm{Pb}$ and $\mathrm{Cu}$ in the leaves of broad beans (by approx. twofold, and by approx. 39\%). A similar increase in $\mathrm{Cu}$ uptake was noted in tobacco shoots when it was initially cultivated in companion planting with sunflower [1], and this was also found in peanuts intercropped with different cereals [34]. More than a fourfold increase in $\mathrm{Ni}$ content was found in the leaves of broad beans cultivated with sweet alyssum in an $80 \mathrm{~cm}$ row spacing and with white mustard in a $65 \mathrm{~cm}$ row spacing. In the remaining objects, the content of this metal did not differ significantly from the control object. Moreover, the content of aluminium increased almost twofold in all protected objects (both biologically and chemically protected) except for L50, S80, and St80.

\section{Conclusions}

1. Both sweet alyssum and white mustard as accompanying plants in the cultivation of broad beans beneficially affected the morphological parameters and the yield of $V$. faba plant. In the case of $L$. maritima, there is no need to increase the row spacing above the standard, i.e., $50 \mathrm{~cm}$. The thinning procedure applied to $S$. alba did not demonstrate a significant effect upon the growth of broad beans.

2. The nitrogen content in the leaves of broad beans under the effect of neighbouring cultivation of $L$. maritima with the retained standard row spacing of $50 \mathrm{~cm}$ and white mustard with a $65 \mathrm{~cm}$ row spacing significantly decreased (by approx. 6\%), which can signify the existence of competition for this element from both plants.

3. The content of macroelements in the leaves of broad beans was diverse, depending on the element: in the case of $\mathrm{Mg}$ and $\mathrm{P}$, the decreased content was noted, while the content of $\mathrm{Ca}$ and $\mathrm{K}$ in some cases increased under the effect of the applied method of protection.

4. The content of microelements and heavy metals usually either did not fluctuate widely, or increased $(\mathrm{Fe}, \mathrm{Ni}$, and $\mathrm{Al})$. Only in the case of $\mathrm{Zn}$ was there an evident decrease in its content in the leaves of broad beans growing close to L. maritima plants.

\section{Acknowledgements}

Scientific publication was financed by the Ministry of Science and Higher Education of the Republic of Poland.

\section{Conflict of Interest}

The authors declare no conflict of interest.

\section{References}

1. KIDD P., MENCH M., ALVAREZ-LOPEZ V., BERT V., DIMITRIOU I., FRIESL-HANL W., HERZIG R., JANSSEN J.O., KOLBAS A., MUELLER I., NEU S., RENELLA G., RUTTENS A., VANGRONSVELD J., PUSCHENREITER M. Agronomic Practices for Improving Gentle Remediation of Trace ElementContaminated Soils. Int. J. Phytoremediat. 17, 1005, 2015. doi:10.1080/15226514.2014.1003788.

2. HOGG B.N., BUGG R.L., DAANE K.M. Attractiveness of common insectary and harvestable floral resources to beneficial insects. Biological Control. 56, 76, 2011.

3. VAN RIJN P.C.J., WACKERS F.L. Nectar accessibility determines fitness, flower choice and abundance of hoverflies that provide natural pest control. J. Appl. Ecol. 53, 925, 2016.

4. SEIDENGLANZ M., HUŇADY I., POSLUŠNA J., LOES A.K. Influence of intercropping with spring cereals on the occurrence of pea aphids (Acyrthosiphon pisum Harris, 1776) and their natural enemies in field pea (Pisum sativum L.). Plant Protect. Sci, 47, 25, 2011.

5. SĄDEJ W., WALERYS G., TWORKOWSKI J. Alternative plants as a factor stimulating occurrence of entomophages. Prog. Plant Prot. 47, 202, 2007.

6. WNUK A., WIECH K. The effect of spacing, date of sowing and intercropping on the occurrence of pea pests. Roczn. Nauk Roln. / E Ochrona Roślin 25 (1/2), 9, 1996.

7. WNUK A. Effect of intercropping of pea with tansy phacelia and white mustard on occurrence of pests. Folia Hort. 10 (1), 67, 1998.

8. GOSPODAREK J., KACZMARCZYK M., RUSIN M., BINIAŚ B. The effect of white mustard proximity on broad bean infestation with black bean aphid (Aphis fabae Scop.). J. Res. Appl. Agric. Engng. 61 (3), 156, 2016.

9. TRINGOVSKA I., YANKOVA V., MARKOVA D., MIHOV M. Effect of companion plants on tomato greenhouse production. Sci. Hortic. 186, 31, 2015.

10. BIRKÁS M., JOLÁNKAI M., GYURICZA C., PERCZE A. Tillage effects on compaction, earthworms and other soil quality indicators in Hungary. Soil Tillage Res. 78, 185, 2004.

11. SCHRÖDER D., KÖPKE U. Faba bean (Vicia faba L.) intercropped with oil crops - a strategy to enhance rooting density and to optimize nitrogen use and grain production? Field Crop. Res. 135, 74, 2012.

12. ARNO J., OVEJA M.F., GABARRA R. Selection of flowering plants to enhance the biological control of Tuta 
absoluta using parasitoids. Biological Control 122, 41, 2018.

13. GRASSWITZ T.R. Development of an Insectary Plant Mixture for New Mexico and its Effect on Pests and Beneficial Insects Associated with Pumpkins. Southwest. Entomol. 38, 417, 2013.

14. HOGG, B.N. NELSON E.H., MILLS N.J., DAANE K.M. Floral resources enhance aphid suppression by a hoverfly. Entomol. Exp. Appl. 141, 138, 2011.

15. GONTIJO L.M., BEERS E.H., SNYDER W.E. Flowers promote aphid suppression in apple orchards. Biological Control 66, 8, 2013.

16. BARBIR J., BADENES-PÉREZ F.R., FERNÁNDEZQUINTANILLA C., DORADO J. The attractiveness of flowering herbaceous plants to bees (Hymenoptera: Apoidea) and hoverflies (Diptera: Syrphidae) in agroecosystems of Central Spain. Agric. For. Entomol. 17, 20, 2015.

17. ARAJ S.E., WRATTEN S.D. Comparing existing weeds and commonly used insectary plants as floral resources for a parasitoid. Biol. Control 81, 15, 2015.

18. MUNIR S., DOSDALL L.M., KEDDIE A. Selective effects of floral food sources and honey on life-history traits of a pest-parasitoid system. Entomol. Exp. Appl. 166, 500, 2018.

19. BRENNAN E.B. Agronomic aspects of strip intercropping lettuce with alyssum for biological control of aphids, Biol. Control 65 (3), 302, 2013.

20. NADGÓRSKA-SOCHA A., KAFEL A., KANDZIORACIUPA M., GOSPODAREK J., ZAWISZA-RASZKA A. Accumulation of heavy metals and antioxidant responses in Vicia faba plants grown on monometallic contaminated soil. Environ. Sci. Pollut. Res. 20 (2), 1124, 2013.

21. RUSIN M., GOSPODAREK J., NADGÓRSKA-SOCHA A., BARCZYK G. Effect of petroleum-derived substances on life history traits of black bean aphid (Aphis fabae Scop.) and on the growth and chemical composition of broad bean. Ecotoxicology 26, 308, 2017.

22. GOSPODAREK J., KAFEL A. COEXISTENCE OF APHIS FABAE SCOP. PREDATORS ON BROAD BEAN GROWING ON SOIL POLLUTION WITH HEAVY METALS. J. Elem. 19, 95, 2014.

23. WNUK A., GOSPODAREK J. Occurrence of aphidophagous Syrphidae (Diptera) in colonies of Aphis fabae Scop., on its various host plants. Annals of Agricultural Sciences Series E - Plant Protection 18 (1-2), $7,1999$.

24. GOSPODAREK J. Co-occurrence of predators of black bean aphid (Aphis fabae Scop.) on Philadelphus coronarius. Prog. Plant Prot. 52, 20, 2012.

25. BRENNAN E.B. Agronomic aspects of strip intercropping broccoli with alyssum for biological control of aphids. Biol. Control 97, 109, 2016.

26. WIESHAMMER G., UNTERBRUNNER R., GARCIA T.B., ZIVKOVIC M.F., PUSCHENREITER M., WENZEL
W.W. Phytoextraction of $\mathrm{Cd}$ and $\mathrm{Zn}$ from agricultural soils by Salix ssp and intercropping of Salix caprea and Arabidopsis halleri. Plant Soil 298, 255, 2007.

27. HU J.L., CHAN P.T., WU F.Y., WU S.C., ZHANG J.H., LIN X.G., WONG M.H. Arbuscular mycorrhizal fungi induce differential $\mathrm{Cd}$ and $\mathrm{P}$ acquisition by Alfred stonecrop (Sedum alfredii Hance) and upland kangkong (Ipomoea aquatica Forsk.) in an intercropping system. Appl. Soil Ecol. 63, 29, 2013.

28. LI W., LI L., SUN J., GUO T., ZHANG F., BAO X., PENG A., TANG C. Effects of intercropping and nitrogen application on nitrate present in the profile of an Orthic Anthrosol in Northwest China. Agric. Ecosyst. Environ. 105, 483, 2005.

29. LI L., TANG C., RENGEL Z., ZHANG F.S. Calcium, magnesium and microelement uptake as affected by phosphorus sources and interspecific root interactions between wheat and chickpea. Plant Soil 261, 29, 2004. doi:10.1023/b:plso.0000035579.39823.16.

30. XIAO X., CHENG Z., MENG H., LIU L., LI H., DONG Y. Intercropping of Green Garlic (Allium sativum L.) Induces Nutrient Concentration Changes in the Soil and Plants in Continuously Cropped Cucumber (Cucumis sativus L.) in a Plastic Tunnel. Plos One 8, 2013. doi:10.1371/journal. pone.0062173.

31. YILDIZTEKIN M., TUNA A.L., NADEEM S., YILDIZTEKIN F. Effects of mono- and intercropping on growth and boron uptake of wheat plant (Triticum aestivum L.) cultivated on boron-contaminated media. Pakistan J. Bot. 47, 1259, 2015.

32. GUO X., XIONG H., SHEN H., QIU W., JI C., ZHANG Z., ZUO Y. Dynamics in the rhizosphere and iron-uptake gene expression in peanut induced by intercropping with maize: Role in improving iron nutrition in peanut. Plant Physiol. Bioch. 76, 36, 2014. doi:10.1016/j.plaphy.2013.12.019.

33. WICHE O., KUMMER N.A., HEILMEIER H. Interspecific root interactions between white lupin and barley enhance the uptake of rare earth elements (REEs) and nutrients in shoots of barley. Plant Soil 402, 235, 2016. doi:10.1007/s11104-016-2797-1.

34. ZUO Y., ZHANG F. Effect of peanut mixed cropping with gramineous species on micronutrient concentrations and iron chlorosis of peanut plants grown in a calcareous soil. Plant Soil 306, 23, 2008. doi:10.1007/s11104-007-9484-1.

35. MALTAIS-LANDRY G. Legumes have a greater effect on rhizosphere properties $(\mathrm{pH}$, organic acids and enzyme activity) but a smaller impact on soil $\mathrm{P}$ compared to other cover crops. Plant Soil 394, 139, 2015.

36. GOVE B., HUTCHINSON J.J., YOUNG S.D., CRAIGON J., MCGRATH S.P. Uptake of metals by plants sharing a rhizosphere with the hyperaccumulator Thlaspi caerulescens. Int. J. Phytoremediat. 4, 267, 2002. 